\title{
Konservatuvar Öğrencilerinin Eşlik Dersine İlişkin Metaforik Yaklaşımlarının Farklı
}

\section{Değişkenler Açısından İncelenmesi*}

\section{Hepşen OKAN ${ }^{* *}$, Hacer MOHAN KÖMÜRCÜ***}

Öz: $\mathrm{Bu}$ araştırmanın amacı konservatuvar öğrencilerinin eşlik dersine yönelik metaforik yaklaşımlarını belirlemektedir. $\mathrm{Bu}$ çalışma nitel bir araştırma olup, olgubilim deseni kullanılmıştır. Olgubilim araştırmalarında bireyin bir olguya yüklediği anlamların ortaya çıkarılması amaçlanmaktadır. Araştırmanın çalışma grubu, konservatuvarda eğitim gören öğrenciler arasından benzeşik örnekleme yöntemi ile seçilen 104 öğrenciden oluşmuştur. Araştırma verilerinin elde edilmesinde araştırmacılar tarafindan hazırlanan veri toplama formu kullanılmıştır. Formda, öğrencilerin demografik bilgilerinin yanı sıra, "Eşlik dersi gibidir, çünkü ." cümlesini tamamlamaları istenmiştir. Elde edilen veriler içerik analizi yöntemi ile analiz edilmiştir. İçerik analizi ile konservatuvar öğrencilerinin "eşlik dersi” kavramına yönelik geliştirdikleri metaforlar belirlenmiş, ortaya çıkan metaforlar kodlanarak kategorileştirilmiştir. Üretilen metaforların kategorileri ile öğrencilerin demografik değişkenleri arasında bir ilişki olup olmadığını belirlemek için çapraz tablolama analizinden yararlanılmıştır. Araştırma sonucunda, konservatuvar öğrencilerinin eşlik dersine yönelik metaforik yaklaşımlarının "Uyum ve birliktelik unsuru olarak eşlik dersi”, "Kaygı kaynağı olarak eşlik dersi”, "Heyecan ve mutluluk kaynağı olarak eşlik dersi”, "Zorunlu bir ihtiyaç olarak eşlik dersi”, "Tamamlayıcı bir unsur olarak eşlik dersi”, "Destekleyici bir unsur olarak eşlik dersi", "Yol gösterici, öğretici bir unsur olarak eşlik dersi" olmak üzere 7 kategoride toplandığı tespit edilmiştir.

Anahtar Kelimeler: Müzik eğitimi, konservatuvar eğitimi, eşlik dersi, metafor, olgubilim

\footnotetext{
*Ankara Üniversitesi Etik Kurulu Sosyal Bilimler Alt Etik Kurulu’nun 30/03/2020 tarih ve 3/67 say1l1 karar1 gereği çalışma ilgili çalışmanın, etik açıdan uygun olduğuna oy birliği ile karar verilmiştir.

${ }^{* *}$ Dr. Öğr. Üyesi Ankara Üniversitesi, Devlet Konservatuvarı. Müzik Bölümü, okanhepsen@gmail.com, https://orcid.org/0000-0002-8019-9755

*** Öğr.Gör.Dr. Zonguldak Bülent Ecevit Üniversitesi, Devlet Konservatuvarı, Müzik Bölümü, hacermohan@gmail.com, https://orcid.org/0000-0002-3162-5236
} 
Metaphoric Approaches of Conservatory Students to “Accompaniment Course”

Abstract: The purpose of this study is to determine the metaphorical approaches of conservatory students towards the accompaniment course. This study is a qualitative research and the phenomenology pattern is used. In phenomenology studies, it is aimed to reveal the meanings that an individual attributes to a phenomenon. The study group of the research consisted of 104 student selected by random sampling method among the conservatories. The form prepared by the researchers was used to obtain research data. In the form, besides the demographic information of the students, they were asked to complete the sentence "Accompaniment course is like because .”. The data obtained were analyzed by content analysis method. By content analysis, the metaphors developed by the conservatory students for the concept of "accompaniment course" were determined and the resulting metaphors were coded and categorized. Cross-tab analysis was used to determine whether there is a relationship between the categories of metaphors produced and the demographic variables of the students. As a result of the research, the metaphoric approaches of the conservatory students towards the accompaniment course were grouped into 7 categories. These are "Accompaniment course as an element of harmony and togetherness”, “Accompaniment course as a source of anxiety”, “Accompaniment course as a source of excitement and happiness”, "Accompaniment course as a compulsory necessity”, “Accompaniment course as a complementary element”, “Accompaniment course as a supportive element”, “Accompaniment course as guiding and instructive element”.

Keywords: Music education, conservatory education, accompaniment course, phenomenology

\section{Giriş}

Metaforlar, antik Yunan'dan günümüze değin gelen retorik sanatının önemli unsurlarından biridir. Retorik sanatı ile varlığını güçlendiren metafor kullanımı, sonraki dönemlerde de yazarların dili süslemek için başvurdukları en etkili yöntemlerden biri olmuştur. Grekçe “metaphora” dan gelen metafor kelimesi, etimolojik olarak Grekçe “meta: öte” ve "pherein: taşımak, götürmek" kelimelerinin birleşiminden oluşmakta olup, "öteye taşımak, nakletmek" anlamına gelmektedir (Demirci, 2016). Metafor kavramı Türkçede "eğretileme" veya "istiare" olarak kullanılmasına karşın, bu iki kavramın da "metaforun özünü ıskaladığı" (Demir, 2005, s.13) düşünülmektedir. Eğretileme veya istiare daha çok edebiyatta kullanılan 
diğer mecaz sanatları gibi edebi veya sanatsal bir işlev görürken, metafor kavramı daha çok zihinsel ve düşünsel kavrayış sistemimizi simgelemek için kullanılmaktadır’' (Saban, 2008, s.460).

Metaforların sadece dili, anlatımı süslemek için değil aynı zamanda insanların algılarını ve anlayışlarını da ortaya koyduğuna yönelik ilk düşünceler, dilbilimciler George Lakoff ve Mark Johnson'un 1980 yılında yazmış oldukları “Metaphors We Live By” eserinde ortaya atılmıştır. Lakoff ve Johnson, gündelik dili kuşatan bir metafor sistemi olduğunu iddia eder. $\mathrm{Bu}$ durum yalnızca dille alakalı değil, insan zihninin dünyayı nasıl algıladığıyla alakalıdır. Metafor, insanın dünyayı algılamasını şekillendirmektedir (Lakoff \& Johnson, 1980, s.3). Shuell de (1990) metaforların, herhangi bir olgu hakkında düşünme sistematiğine ilişkin zihinsel bir çerçeve oluşturduğunu belirtmektedir. Sonraki yıllarda yapılan çeşitli çalışmalar, metaforların anlam yaratma ve gerçekliği inşa etme açısından bir enstrüman olduğunu ortaya koymaktadır. Lakoff ve Johnson (2010) metaforu, bilişsel eylemlerin aktarılmasında kullanılan "kavram" alanları olarak ifade etmektedir. Metaforun en genel anlamı, bir düşünceyi onunla ilgilisi olmayan başka bir olgu ile ifade etmektir. Metaforların özelliklerini şu şekilde sıralamak mümkündür: Bir kavramı; farklı bir kavramla tanımlama, farklı bir kavrama benzetme yönüyle betimleme, farklı bir boyutta görme, farklı bir kalıpla yorumlama (Tompkins ve Lawley, 2002, s.2). Eğitim dünyasının çeşitli boyutlarında, öznelerin eğitimi nasıl algılayıp kavradıklarını ortaya koymaya yönelik pek çok metafor araştırması bulunmaktadır (Erdamar \& Akpunar, 2017; Gültekin, 2013; Örücü, 2014; Özaydın, 2019).

İnsanın eğitim sürecinin önemli bir boyutu genel olarak sanat, özel olarak ise müzik eğitimidir. İnsanın müziksel davranışlarını kendi yaşantısı yoluyla istendik yönde değiştirmeyi amaçlayan müzik eğitiminin boyutlarından biri de mesleki müzik eğitimidir. Mesleki müzik eğitimi, müzisyenliği meslek olarak seçmek isteyen bireylere verilen planlı ve programlı eğitim sürecidir. Mesleki müzik eğitimi veren kurumların başında sanatçı yetiştiren konservatuvarlar gelmektedir. Konservatuvarlar, ülkenin müzik ve sahne sanatları alanındaki sanatçı ihtiyacını karşılamakta, öğrencilerin sahip oldukları yetenekleri potansiyellerinin en üst seviyesinde kullanabilmelerine yönelik öğretim planları uygulamaktadır. Konservatuvarların öğretim planlarında yer alan ana unsurlarından biri de eşlik dersidir. Eşlik dersi, öğrencinin çalgısını ya da sesini, piyano eşliği ile birlikte kullanabilmesine yönelik öğrencide istenilen yönde davranış edindirme ya da geliştirme süreci olarak tanımlanabilir. Dersin sorumlu öğretim elemanı, eşlik çalgısını kullanan “eşlikçi” ya da bir diğer adıyla "korrepetitör”dür. 
Pala ve diğerlerinin de (2016) belirttiği gibi, eşlik dersinde kullanılan başat çalgılardan biri piyanodur. Eşlik dersinde piyano kullanılmasının temel nedeni armonik çoksesliliği sağlayabilmesidir. Piyano, yedi oktavlık bir aralık içerisinde, bir orkestranın seslendirebileceği tüm perdeleri kapsar ve tek bir kişinin on parmağı, yüzden fazla orkestra çalgısının meydana getirdiği birlik tarafından ortaya çıkartılan armonileri yeniden duyurmak için yeterlidir. Buna göre, piyanonun orkestra eseri ile ilişkisi, bir kabartmanın bir tablo ile olan ilişkisiyle aynı temele dayanır: Piyano, orijinal eseri çoğaltır, onu herkes için ulaşılabilir kılar ve renkleri yansıtamasa bile 1şık ve gölgeleri yansıtabilir (Roberge, 1993, s.925). Piyanoyu orkestraya alternatif olarak kullanabilmek için, hemen hemen tüm konçerto ve diğer orkestra eşlikli solo çalgı eserleri ve bale, konser aryaları, orkestra eşlikli kantatlar, requemler, oratoryo, operet, opera ve müzikaller gibi sahne eserlerinin orkestra partitürleri, piyano yazısına indirgenmiştir. İngilizcede "Piano reduction" ya da vokal eserler için "Vocal score" adı verilen ancak Türkçede tam karşıllı̆ı bulunmayan bu indirgenmiş partitürler için "Piyano eşliği düzenlemesi" tanımı kullanılabilir. Vokal müzikte, bir opera aryasının ya da düet, terzet, kuartet gibi bölümlerinin hazırlık çalışmalarında, koro, sahne provalarında, yarışmalarda, sınavlarda, derslerde ve piyano eşlikli resitallerde de bu düzenlemeler kullanılır (Artaç, 2012, s.230).

Eşlik dersini yürüten eşlikçiden (korrepetitörden) müzikal sunumun bir parçası olması, soliste destek vererek onun yorumuna uyum sağlaması aynı zamanda solistin tamamlayıcısı olması beklenmektedir. Korrepetitör, eserin ilk çalışılmasından olgunlaşmasına kadar olan süreçte solisti birebir yetiştirir, performansa hazırlar (Kömürcü, 2019, s.33). Piyano eşlikçisi diğer enstrümanlarla birlikte performans yaptıkları için, müzikal, sosyal vb. diğer becerilere sahiptir. Enstrümantal, vokal solistlerin ve piyano eşlikçilerinin performansları esnasında enstrüman kategorilerine göre ve vokal özelliklerine uygun olarak karş1lıklı olarak belirli beklentileri vardır (Roussou, 2017, s.6). Örneğin piyanist, şancı ile birlikte nefes almalıdır. Şancının akciğerlerini düşünerek, ona nefes, soluk alma firsatı vermelidir. Şancı söylerken cümlelerin bütünlüğünü bozmadan, müzik cümlelerinin akışını düşünmelidir. Her notayı ayrı ayrı düşünmek yanlış yoruma yol açabilir (Demirova, 2010, s.262). Yukarıdaki örneklerden anlaşılacağı üzere, şancılara, nefeslilere ve yaylı enstrümanlara eşlik etmek, beraber müzik yapabilmek farklı özellik ve dinamiklere sahiptir. Bu süreçte eşlikçi ve solist konumunda performans yapan kişi, bu özelliklerin farkında olabilmeli ve performansını bu yönde yetkinleştirebilmelidir. 
Eşlik dersi, mesleki eğitim veren kurumlarda solist icracının, birlikte çalmaya yönelik icra etme prensiplerini öğrendiği ve uyguladığı bir ders olarak yerini almaktadır. Bu dersin enstrüman ve şan eğitimi alan öğrencilere, piyano eşliğiyle birlikte kendi partisini icra edebilme, duyabilme, çalmış oldukları eserin içeriği, formu, stil ve dönem özelliklerine dair kavrama ve birlikte yorumlama becerilerini kazandırması bakımından mesleki müzik eğitiminde uygulamaya dayalı önemli bir rolü olduğu söylenebilir.

Konservatuvar eğitimini metaforik yaklaşım açısından inceleyen az sayıda çalışma bulunmaktadır. Akdeniz ve Çarkçı (2017), konservatuar öğrencilerinin "Sanat Eğitimi”" kavramına ilişkin metaforik algılarını incelemiş ve çalışma grubu tarafından üretilen 52 farklı metafor ortak özellikleri ve sanat eğitimi ile kurdukları ilişki bakımından 5 kategori altında toplanmıştır. Konservatuvar öğrencilerinin sanat eğitimini, temel ihtiyaç olması, yaratıcılığı desteklemesi, çaba gerektirmesi, hayatın bir parçası olması, kişisel gelişim ve öğrenmeyi desteklemesi ve duyguların ifadesi olması yönüyle ele aldıkları sonucuna ulaşılmıştır. Eğitim alanındaki metaforik yaklaşımlara yönelik araştırmalar genel olarak incelendiğinde; eğitim ve eğitim yönetimi alanlarında kavram ya da olguların, çalışma grubunda bulunan katılımcılar tarafından hangi metaforlarla ifade edildiği ortaya çıkmaktadır (Kalyoncu, 2012, s.472). Bu bağlamda, konservatuvar öğrencilerinin eşlik derslerine ilişkin yaklaşımlarının metafor yoluyla ortaya konulmasının önemli olduğu düşünülmektedir. $\mathrm{Bu}$ araştırmada, konservatuvar öğrencilerinin eşlik dersine ilişkin metaforik yaklaşımlarının ortaya konulması amaçlanmaktadır.

\section{Araştırmanın Amacı}

$\mathrm{Bu}$ araştırmanın amacı, konservatuvar öğrencilerinin eşlik dersine yönelik metaforik yaklaşımlarını belirlemektedir. $\mathrm{Bu}$ amaç doğrultusunda aşağıdaki araştırma soruları geliştirilmiştir.

1-) Konservatuvar öğrencilerinin eşlik derslerine ilişkin sahip oldukları metaforlar nelerdir?

2-) Konservatuvar öğrencilerinin eşlik derslerine ilişkin sahip oldukları metaforlar, hangi kavramsal kategoriler altında toplanabilirler?

3-) Konservatuvar öğrencilerinin eşlik dersine yönelik metaforik yaklaşımlarında cinsiyet değişkeni bağlamında anlamlı bir farklılık var mıdır?

4-) Konservatuvar öğrencilerinin eşlik dersine yönelik metaforik yaklaşımlarında yaş değişkeni bağlamında anlamlı bir farklılık var mıdır? 
5-) Konservatuvar öğrencilerinin eşlik dersine yönelik metaforik yaklaşımlarında sınıf değişkeni bağlamında anlamlı bir farklılık var mıdır?

6-) Konservatuvar öğrencilerinin eşlik dersine yönelik metaforik yaklaşımlarında branş değişkeni bağlamında anlamlı bir farklılık var mıdır?

\section{Yöntem}

\section{Araştırmanın Deseni}

$\mathrm{Bu}$ çalışma nitel bir araştırma olup konservatuvar öğrencilerinin eşlik dersine ilişkin yaşadıkları deneyimleri değerlendirmeye odaklanması bakımından olgubilim desenindedir. Miller da (2003) olgubilim yöntemini, yaşanmış olan deneyimleri değerlendirmeye odaklanan bir yöntem olarak tanımlamaktadır. Olgubilim çalışmaları, ele alınan olay ya da olgularla ilgili bireyin davranışlarını biçimlendiren anlamları, kavrayışları belirlemeyi ve yorumlamayı amaçlamaktadır (Willig, 2008). Bir başka ifade ile olgubilim, yaşantımızda yer alan ancak yüzeysel bilgiye sahip olduğumuz olay, kavram, eğilim gibi olguların derinlemesine irdelenmesini içerir. Yıldırım ve Şimşek de (2013) yabancı olmadığımız ancak tam olarak anlamını kavrayamadığımız olguların araştırılmasında olgubilim yönteminin uygun bir zemin oluşturduğunu belirtmektedir. $\mathrm{Bu}$ araştırmada olgubilim deseni kullanılarak konservatuvar öğrencilerinin eşlik dersine yönelik davranışlarının altında yatan metaforik anlamlar belirlenmeye çalışılmıştır.

\section{Çalışma Grubu}

Araştırmanın amaç ve kapsamına bağlı olarak, çalışma grubunun ele alınan olguyla ilgili yaşantısı olan bireylerden seçilmesi gerekliliği bulunduğundan, Patton'un benzeşik örnekleme yöntemi benimsenmiştir (2002). Bu nedenle benzeşik bir çalışma grubunun oluşturulmasında, öğrencilerin araştırılan olguyla ilgili deneyimlerinin bulunması göz önünde bulundurulmuştur. Seçkisiz örnekleme yöntemi ile belirlenen çalışma grubu, Türkiye’de bulunan 4 konservatuvarda eşlik dersini alan toplam 104 konservatuvar öğrencisinden oluşturulmuştur. Araştırma kapsamında çalışma grubunda yer alan öğrenciler Ö1, Ö2, Ö3................̈104 şeklinde kodlanmıştır.

\section{Veri Toplama Aracı}

Araştırma verileri, araştırma kapsamında ele alınan eşlik dersi olgusuyla ilgili yaşantısı ve deneyimi olan konservatuvar öğrencilerinden, araştırmacılar tarafından hazırlanmış olan form ile toplanmıştır. Araştırmacılar tarafından oluşturulan veri toplama formu iki kısımdan oluşmaktadır. Formun ilk kısmında öğrencilerin sınıf, yaş, cinsiyet ve branşlarına ilişkin 
bilgileri toplamaya yönelik sorular yer almıştır. Formun ikinci kısmında ise "Eşlik dersi gibidir, çünkü. .” ifadesi yazılmış ve öğrencilerden eşlik dersinin özelliklerini

düşünerek cümlenin ilk kısmına bir metafor tanımlamaları istenmiştir. Araştırmacılar tarafından hazırlanan form uzman görüşleri doğrultusunda düzeltilmiş ve araştırma için son hali verilmiştir. Cümlenin “çünkü” diye başlayan ikinci kısmında ise neden o metaforu kullandıklarını açıklamaları istenmiştir. Böylelikle, öğrencilerin eşlik dersi ile ilgili metaforik yaklaşımlarına ilişkin verileri toplanmıştır. Toplanan veriler 1şı̆̆ında öğrencilerin ürettikleri metaforların kategorileri ile öğrencilerin demografik değişkenleri arasında bir ilişki olup olmadığı belirlenmeye çalışılmıştır.

\section{Verilerin Analizi}

Araştırma kapsamında elde edilen veriler içerik analizi yöntemi ile analiz edilmiştir. İçerik analizi yöntemi dört adımda uygulanmıştır. İlk olarak, veriler excel programında alfabetik sıraya göre kodlanmıştır. Bu kodlama aşamasında çalışma grubundan elde edilen verilerin dökümü yapılmış, her bir formda üretilen metaforlar ve demografik değişkenlere ait bilgiler kontrol edilmiştir. İkinci olarak, çalışma grubu tarafından üretilen her bir metaforu en iyi ifade eden kavram belirlenmiş, ortak anlamlar içeren kavramlar çerçevesinde temalar oluşturulmuş ve metaforların temalar altında gruplanması sağlanmıştır. Yıldırım ve Şimşek (2013) de içerik analizinde, toplanan verilerin araştırmanın amacı doğrultusunda kavramsallaştırılması ve bu kavramlara göre temaların belirlenmesi gerektiğini belirtmektedir. Üçüncü olarak, kodlamalara göre organize edilen temalar ışı̆̆ııda, alan yazınındaki kaynaklar da göz önünde bulundurularak kategoriler oluşturulmuştur. Dördüncü adımda ise belirlenen kategoriler, öğrencilerin demografik değişkenleri bağlamında analiz edilerek bulgular tanımlanmıştır. Kodlama süreci bilgisayar ortamında yapılmış olup SPSS 19 programından yararlanılmıştır. Veri setinin çeşitli bölümlerinde birbiriyle ilişkili olan kodlar temalar altında birleştirilmiş ve bu bilgiler kategoriler ilişkisi bağlamında açıklanmaya çalışılmıştır. Kategorilerin görülme sıklığı ve değişkenlerle ilişkisini belirlemek için frekans analizlerinden yararlanılmıştır. Tavşancıl ve Aslan'ın (2001) belirttiği gibi nitel araştırmalarda frekans analizi yardımıyla öğelerin nicel olarak görülme sıklığı belirlenebilir ve bu yolla öğelerin önem ve etki derecelerine ilişkinin yorum yapılabilir.

Araştırma kapsamında verilerin geçerlik ve güvenirliğini sağlamak için kodlamalar, temaların belirlenmesi ve kategorin geliştirilmesi her bir araştırmacı tarafından bağımsız olarak yapılmıştır. Birbirinden bağımsız olarak elde edilen kategoriler araştırmacılar tarafından 
karşılaştırılarak benzer ve farklı yönler tespit edilmiş ve alan yazını 1şığında yapılan tartışmalar sonucunda asıl liste oluşturulmuştur. Oluşturulan kategoriler ve çalışma grubundan elde edilen metaforlar, üç farklı uzman tarafından eşleştirilmiş, bu kodlama işlemi sonucunda kodlayıcılar arası uzlaşma katsayısı ölçülmüştür. Kodlayıcılar arası uzlaşma, tüm ölçekler için kullanılabilen Krippendorff Alpha katsayısı ile hesaplanmıştır. Krippendorff Alpha güvenirlik katsayısı $0 \leq \alpha \geq 1$ değer alır. $\alpha=1$ olması kodlayıcılar arasında mükemmel bir uyumun olduğunu, $\alpha=0$ 'a yaklaşması ise uyumun zayıflığını göstermektedir. Alfa katsayısı $\alpha \geq 0,80$ ise kodlayıcılar arası uyumun yüksek düzeyde olduğuna, $0,67<\alpha>0,80$ ise kodlayıcılar arasında orta düzeyde bir uyum olduğuna, $\alpha \leq 0,67$ ise kodlayıcılar arası uyumun zayıf düzeyde olduğuna işaret eder (Krippendorff ve Bock, 2008). Bu araştırmada kodlayıcılar arası uyum katsayısı $\alpha=, 9944$ olarak hesaplanmıştır. Bu çalışmada yapılan kodlamalarda kodlayıcılar arası uyumun yüksek düzeyde olduğu görülmektedir.

Öğrencilerin demografik değişkenleri ile kategoriler arasındaki ilişkiler, çapraz tablo analizi ile frekans ve yüzde şeklinde sunulmuştur.

\section{Bulgular}

Konservatuvar öğrencilerinin eşlik dersine ilişkin ürettikleri metaforlar Tablo 1'de verilmiştir.

Tablo 1.Konservatuvar Öğrencilerinin "Eşlik Dersi”ne İlişkin Ürettikleri Metaforlar

\begin{tabular}{llllll}
\hline Metafor & f & Metafor & f & Metafor & f \\
\hline Nefes & 1 & Meze & 1 & Oksijen & 1 \\
\hline Ateş & 1 & Yağmur & 1 & Makyaj & 1 \\
\hline Yüzmek & 1 & Spor & 1 & Çiçek & 1 \\
\hline İlaç & 1 & Sohbet & 1 & İp & 1 \\
\hline Survivor & 1 & Bisiklet Sürmek & 1 & Masal Kitabı & 1 \\
\hline Strateji Kurmak & 1 & Anahtar & 2 & Uzun yolda araba kullanmak & 1 \\
\hline Yol arkadaşı & 1 & Sigara-çakmak & 1 & Tren & 1 \\
\hline Müziğin yarısı & 1 & Akşamsefası çiçeği & 1 & Deniz feneri & 1 \\
\hline Sevgili & 2 & Tahterevalli & 1 & Teknik direktör & 1 \\
\hline Yapboz & 4 & Kirlarda koşup oynamak & 1 & Domino taşları & 1 \\
\hline Yapı ve onarım & 1 & Paraşüt yapma & 1 & Bir binanın temeli & 1 \\
\hline Parlayan bir yıldız & 1 & Fotoğraf çekmek & 1 & Mor renk & 1 \\
\hline Orkestra şefi & 1 & Ruh & 1 & Kiş mevsimi & 1 \\
\hline İhtiyaç & 1 & Yol & 1 & Keşif yolculuğu & 1 \\
\hline Terapi & 3 & Halat çekme yarışı & 1 & Bale yapmak & 1 \\
\hline Şan dersi & 1 & Kucaklama & 1 & Yoğun bakımda kalp atışımız & 1 \\
\hline Akarsu & 2 & Piyanonun siyah tuşları & 1 & Bütün & 3 \\
\hline Güneş & 1 & Giysi & 1 & Çimento & 1 \\
\hline Su & 2 & Uçmak & 2 & Kuşlar & 1 \\
\hline
\end{tabular}




\begin{tabular}{llllll}
\cline { 3 - 5 } Parfüm & 1 & Gökkuşağı & 1 & Dünyanın dönüşü & 1 \\
\hline Dans & 7 & Aşk & 2 & Arazide jeep kullanmak & 1 \\
\hline Sahne & 1 & Baharat & 1 & Yolcu & 1 \\
\hline Şans & 1 & Ruh ikizi & 1 & Anne & 1 \\
\hline Orkestra & 1 & Yaşam Koçu & 1 & İki dünya arasında köprü & 1 \\
\hline Keşif & 1 & $\begin{array}{l}\text { Piyano öğrenmedeki } \\
\text { mutluluk }\end{array}$ & 1 & Şanın tamamlanması & 1 \\
\hline Enstrüman dersi & 1 & Şan dersi & 1 & Özlem & 1 \\
\hline Heykeltraş & 1 & Tatlı & 1 & Keyif & 1 \\
\hline Dost & 1 & Iyilik & 1 & Anahtar-kilit & \\
\hline Duygu & 1 & & & & 1 \\
\hline
\end{tabular}

Konservatuvar öğrencileri eşlik dersini ifade etmek için toplam 85 adet metafor üretmişlerdir. Bu metaforlar içinde eşlik dersi en çok dans (8) metaforu ile ifade edilmiştir. Bu metaforu sirası ile yapboz (5), anahtar (3), terapi (3) ve akarsu (3) metaforları takip etmektedir.

Elde edilen metafor tablosunun kavramsal olarak kodlanması ile toplam 7 adet kategori belirlenmiştir. Bu kategoriler şu şekilde oluşturulmuştur.

1. Uyum ve birliktelik unsuru olarak eşlik dersi

2. Kaygı kaynağı olarak eşlik dersi

3. Mutluluk kaynağı olarak eşlik dersi

4. Zorunlu bir ihtiyaç olarak eşlik dersi

5. Tamamlayıcı bir unsur olarak eşlik dersi

6. Destekleyici bir unsur olarak eşlik dersi

7. Yol gösterici, öğretici bir unsur olarak eşlik dersi

Kodlama sürecinin sonunda kategoriler arası anlamlar bağlamında, “uyumlu müzikal birliktelik", "performans alanını bütünleyici" ve "kaygı uyandırıcı" bir ders olarak üç ana temaya ulaşılmıştır. Uyumlu müzikal birlikteliği öğretici ve performans alanını bütünleyicidestekleyici temaları eşlik dersine ilişkin alanyazında tanımlanan amaç ve hedeflerle örtüşmektedir.

Eşlik dersi temel olarak, icracıların uyumlu bir şekilde beraber müzik yapabilmesine yönelik uygulamalı bir ders olarak tanımlanabilir. Bu bağlamda "uyumlu müzikal birlikteliği öğretici”, "performans alanını bütünleyici” temaları eşlik dersine yönelik olumlu bir eğilim olarak varsayılabilir.

En az ağırlığa sahip kaygı uyandırıcı teması ise, daha çok şan ve nefesli sazlar ait performans alanlarıdır. Bu derse ilişkin kaygı, bilişsel, psiko-motor ve duyuşsal gibi çeşitli unsurlardan kaynaklanabilir. Eşlik dersinde müzikal uyum ve zamanlama en belirleyici öğeler olarak tanımlanabilir. Şancıların, nefes ve solunum üzerinden performans yapmalarına bağlı 
olarak, müzikte tempoyu ve ritmi hem söz, hem de nefesler açısından daha serbest yorumlamaları birliktelik açısından zorluk ve kaygı yaratan bir unsur olarak değerlendirilebilir.

Benzer şekilde nefesli sazların da nefes ve solunum üzerinden performans yapmalarına bağlı olarak nefesi kullanma kapasitesi ve yeterliliği açısından eşlikle çalmada zorlanabilecekleri söylenebilir. Şan ve nefesli saz öğrencilerinin bilişsel yaklaşımlarının, uyumlu müzikal birliktelikten daha çok eşlik dersini bütünleyici-destekleyici tanımlamaları doğru olmakla birlikte, bu dersin ana kazanımından daha çok ikincil kazanımı olarak kabul edilebilir. Bu performans alanlarındaki öğrencilerin gerek fiziki olarak, gerek bilişsel yaklaşımlarına bağlı olarak eşlik öğretmenleriyle diğer performans alanlarına göre daha zor müzikal uyum sağlayabilecekleri varsayılabilir. Buna bağlı olarak bu temanın, diğer performans alanlarına göre daha olumsuz bir eğilim gösterdiği söylenebilir.

Eşlik dersine ilişkin konservatuvar öğrencileri tarafindan üretilen metaforların kategoriler bağlamında dağılımı Tablo 2'de verilmiştir.

Tablo 2. "Eşlik Dersi”ne İlişskin Metaforların Kavramsal Kategorilere Göre Dağılımı

\begin{tabular}{|c|c|c|c|}
\hline Kategoriler $(n=7)$ & $\begin{array}{c}\text { Kategoriyi } \\
\text { oluşturan } \\
\text { öğrenci sayısı } \\
\text { (f=104 } \\
\text { \%100) } \\
\end{array}$ & Metaforlar $(n=85)$ & $\begin{array}{l}\text { Metafor } \\
(\mathbf{f}=85 \\
\% 100\end{array}$ \\
\hline $\begin{array}{l}\text { Uyum ve } \\
\text { birliktelik unsuru } \\
\text { olarak eşlik dersi }\end{array}$ & $\begin{array}{l}f=25 \\
\% 24\end{array}$ & $\begin{array}{l}\text { Parlayan bir yıldız 1, Dans 7, Sahne 1, Yağmur 1, } \\
\text { Sohbet 1, Yapboz 1, Tahterevalli 1, Fotoğraf } \\
\text { çekmek 1, Gökkuşağ1 1, Aşk 2,Özlem 1, Ruh ikizi } \\
\text { 1, Makyaj yapmak 1, İp 1, Trenler ve raylar 1, } \\
\text { Heykeltıraş 1, Mor renk 1, Dünyanın dönüşü } 1\end{array}$ & $\begin{array}{c}\mathrm{f}=18 \\
\% 21,18\end{array}$ \\
\hline $\begin{array}{l}\text { Kayg1 kaynağı } \\
\text { olarak eşlik dersi }\end{array}$ & $\begin{array}{l}\mathrm{f}=9 \\
\% 8,7\end{array}$ & $\begin{array}{l}\text { Denizde yüzmek 1, Survivor } 1 \text {, Halat çekme yarış1 } \\
\text { 1, Akarsu 2, Domino taşları 1, Kış mevsimi 1, } \\
\text { Yoğun bakımda kalp atış1 1, Arazide jeep } \\
\text { kullanmak } 1\end{array}$ & $\begin{array}{c}\mathrm{f}=8 \\
\% 9,41\end{array}$ \\
\hline $\begin{array}{l}\text { Heyecan ve } \\
\text { mutluluk kaynağı } \\
\text { olarak eşlik dersi }\end{array}$ & $\begin{array}{c}\mathrm{f}=13 \\
\% 12,5\end{array}$ & $\begin{array}{l}\text { Terapi 3, Tatlı 1, Akşamsefası çiçeği 1, Kırlarda } \\
\text { koşup oynamak 1, Uçmak 2, Piyano öğrenmedeki } \\
\text { mutluluk 1, Keşif yolculuğu 1, Bale yapmak 1, } \\
\text { Kuşlar 1, Keyif } 1\end{array}$ & $\begin{array}{c}\mathrm{f}=10 \\
\% 11,76\end{array}$ \\
\hline $\begin{array}{l}\text { Zorunlu bir ihtiyaç } \\
\text { olarak eşlik dersi }\end{array}$ & $\begin{array}{l}\mathrm{f}=8 \\
\% 7,7\end{array}$ & $\begin{array}{l}\text { Nefes } 1 \text {, Ateş } 1 \text {, İlaç } 1 \text {, Su 2, Sigara-çakmak 1, } \\
\text { Oksijen } 1 \text {, Şanın tamamlanması } 1\end{array}$ & $\begin{array}{c}\mathrm{f}=7 \\
\% 8,23\end{array}$ \\
\hline $\begin{array}{l}\text { Tamamlayıı bir } \\
\text { unsur olarak eşlik } \\
\text { dersi }\end{array}$ & $\begin{array}{c}\mathrm{f}=19 \\
\% 18,3\end{array}$ & $\begin{array}{l}\text { Yol arkadaş1 1, Müziğin yarısı 1, Yapboz 4, } \\
\text { İhtiyaç 1, Parfüm 1, Bütün 3, Meze 1, Ruh 1, } \\
\text { Kucaklama 1, Piyanonun siyah tuşları 1, Giysi 1, } \\
\text { Dans 1, Baharat 1, Dost } 1\end{array}$ & $\begin{array}{c}\mathrm{f}=14 \\
\% 16,47\end{array}$ \\
\hline $\begin{array}{l}\text { Destekleyici bir } \\
\text { unsur olarak eşlik } \\
\text { dersi }\end{array}$ & $\begin{array}{l}\mathrm{f}=20 \\
\% 19,2\end{array}$ & $\begin{array}{l}\text { Yüzmek 1, Strateji kurmak 1, Sevgili 2, Yapı ve } \\
\text { onarım 1, Güneş 1, Nefes 1, Spor 1, Bisiklet } \\
\text { sürmek 1, Çiçek 1, Masal kitabı 1, Uzun yolda } \\
\text { araba kullanmak 1, Enstrüman dersi 1, Tren 1, Bir } \\
\text { binanın temeli 1, Anahtar 2, Çimento 1, Yolcu 1, } \\
\text { Anne 1 }\end{array}$ & $\begin{array}{c}\mathrm{f}=18 \\
\% 21,18\end{array}$ \\
\hline
\end{tabular}


Yol gösterici, öğretici bir unsur $\mathrm{f}=10$ $\% 9,6$
Orkestra şefi 1, Şan dersi 1, Orkestra 1, İyilik 1, Anahtar-kilit 1, Duygu 1, Yol 1, Yaşam koçu 1, Deniz feneri 1, Teknik direktör 1 $\mathrm{f}=10$

$\% 11,76$

Tablo 2’ye göre, öğrenciler eşlik dersini en çok uyum ve birliktelik unsuru olarak görmektedir (\%24). Bu kategoriyi eşlik dersinin destekleyici $(\% 19,2)$ ve tamamlayıcı $(\% 18,3)$ unsurları takip etmektedir. Öğrencilerin \%12,5'i eşlik dersini heyecan ve mutluluk kaynağ1 olarak görürken eşlik dersinin duyuşsal boyutunu vurgulamışlar, \%9,6's1 ise eşlik dersini yol gösterici, öğretici bir unsur olarak ifade ederek bilişsel boyutuna vurgu yapmışlardır. Ortaya çıkan kategoriler içinde sadece bir kategori eşlik dersine ilişkin olumsuz ifade içermektedir. Çalışma grubunda yer alan öğrencilerin \%8,7'si eşlik dersini kaygı kaynağı olarak görmektedir. Eşlik dersini kaygı kaynağı olarak gören öğrencilerden Ö5, eşlik dersi için “survivor” metaforunu kullanmış, eşliği yakalayıp uyum sağlamak gerektiğini, eserlerde uyumun zor olan bir durum olduğunu ifade etmiştir. Ö104 ise, “arazide jeep kullanmak” metaforunu kullanmış, “çünkü önünüze birçok engeller çıkar” tanımlamasını yapmıştır.

Tablo 3. “Eşlik Dersi”ne İlişkin Kategorilerin Cinsiyet Değişkeni Bağlamında Dağılımı

\begin{tabular}{lcccc}
\hline Kategori & \multicolumn{2}{c}{ Kız } & \multicolumn{2}{c}{ Erkek } \\
\hline Uyum ve birliktelik unsuru olarak eşlik dersi & $\mathbf{f}$ & $\mathbf{\%}$ & $\mathbf{f}$ & 30 \\
\hline Kaygı kaynağı olarak eşlik dersi & 16 & 21.6 & 9 & 6,7 \\
\hline Heyecan ve mutluluk kaynağı olarak eşlik dersi & 7 & 9,5 & 2 & 26,7 \\
\hline Zorunlu bir ihtiyaç olarak eşlik dersi & 5 & 6,8 & 8 & 0 \\
\hline Tamamlayıcı bir unsur olarak eşlik dersi & 8 & 10,8 & 0 & 6,7 \\
\hline Destekleyici bir unsur olarak eşlik dersi & 17 & 23 & 2 & 26,7 \\
\hline Yol gösterici, öğretici bir unsur olarak eşlik dersi & 9 & 16,2 & 8 & 3,3 \\
\hline Toplam & 74 & 12,2 & 1 & 100 \\
\hline \multicolumn{1}{c}{ Tablo 3’te öğrencilerin eşlik dersine } & ilişkin metaforik yaklaşımlarına yönelik
\end{tabular}

oluşturulan kategorilerin cinsiyet değişkeni bağlamında dağılımları verilmiştir. Tablo 3 incelendiğinde kız öğrencilerin eşlik dersini en çok branş dersini tamamlayıcı bir unsur olarak, erkek öğrencilerin ise eşlik dersini en çok uyum ve birliktelik unsuru olarak gördükleri anlaşılmaktadır. Eşlik dersinin kaygı kaynağı olarak görülmesinde cinsiyet değişkeni açısından belirgin bir fark görülmemektedir. Eşlik dersinin heyecan ve mutluluk kaynağı olarak görülmesinde erkek öğrencilerin oranı kız öğrencilere göre oldukça yüksektir. Erkek öğrencilerin eşlik dersini bir "zorunluluk” olarak görmemeleri dikkat çekicidir. Eşlik dersinin tamamlayıcı boyutunda kız öğrencilerin oranı, destekleyici boyutunda ise erkek öğrencilerin 
oranı daha yüksektir. Eşlik dersinin yol gösterici, öğretici bir unsur olarak görülmesinde kız öğrencilerin oranı erkek öğrencilere göre yüksektir. Erkek öğrencilerin, eşlik dersini yol gösterici, öğretici bir unsur olarak görme oranının çok düşük olması dikkat çekicidir.

Tablo 4. “Eşlik Dersi”ne İlişkin Kategorilerin Sınıf Değişkeni Bağlamında Dağılımı

\begin{tabular}{|c|c|c|c|c|c|c|c|c|c|c|}
\hline \multirow{2}{*}{ Kategori } & \multicolumn{2}{|c|}{ Hazırlık } & \multicolumn{2}{|c|}{ Lisans 1} & \multicolumn{2}{|c|}{ Lisans 2} & \multicolumn{2}{|c|}{ Lisans 3} & \multicolumn{2}{|c|}{ Lisans 4} \\
\hline & f & $\%$ & $\mathbf{f}$ & $\%$ & $\mathbf{f}$ & $\%$ & f & $\%$ & $\mathbf{f}$ & $\%$ \\
\hline Uyum ve birliktelik unsuru olarak eşlik dersi & 3 & 20 & 2 & 10,5 & 5 & 16,7 & 4 & 28,6 & 11 & 45,8 \\
\hline Kaygı kaynağı olarak eşlik dersi & 1 & 6,7 & 1 & 5,3 & 5 & 16,7 & 0 & 0 & 2 & 8,3 \\
\hline Heyecan ve mutluluk kaynağı olarak eşlik dersi & 3 & 20 & 1 & 5,3 & 6 & 20 & 1 & 7,1 & 2 & 8,3 \\
\hline Zorunlu bir ihtiyaç olarak eşlik dersi & 2 & 13,3 & 2 & 10,5 & 1 & 3,3 & 2 & 14,3 & 1 & 4,2 \\
\hline Tamamlayıcı bir unsur olarak eşlik dersi & 2 & 13,3 & 2 & 10,5 & 8 & 26,7 & 2 & 14,3 & 4 & 16,7 \\
\hline Destekleyici bir unsur olarak eşlik dersi & 3 & 20 & 8 & 42,1 & 3 & 10 & 2 & 14,3 & 3 & 12,5 \\
\hline Yol gösterici, öğretici bir unsur olarak eşlik dersi & 1 & 6,7 & 3 & 15,8 & 2 & 6,7 & 3 & 21,4 & 1 & 4,2 \\
\hline Toplam & 15 & 100 & 19 & 100 & 30 & 100 & 14 & 100 & 24 & 100 \\
\hline
\end{tabular}

Tablo 4'te öğrencilerin eşlik dersine ilişkin metaforik yaklaşımlarına yönelik oluşturulan kategorilerin sınıf değişkeni bağlamında dağılımları verilmişstir. Tablo 4'e göre hazırlık sınıfı öğrencileri eşlik dersini en çok uyum ve birliktelik unsuru, heyecan ve mutluluk kaynağı ve aynı zamanda destekleyici olarak görmektedir. Lisans 1 sınıf öğrencileri ise eşlik dersini en çok branş dersini destekleyici bir ders olarak görmektedir. Lisans 2. sınıf öğrencileri eşlik dersini en çok tamamlayıcı bir unsur olarak görürken, lisans 3. ve 4. sınıflar eşlik dersini en çok uyum ve birliktelik unsuru olarak görmektedir.

Tablo 5. "Eşlik Dersi”ne İlişkin Kategorilerin Yaş Değiş̧keni Bağlamında Dağılımı

\begin{tabular}{lcccccccc}
\hline \multirow{2}{*}{ Kategori } & \multicolumn{2}{c}{$\mathbf{1 8 - 1 9}$} & \multicolumn{2}{c}{$\mathbf{2 0 - 2 1}$} & \multicolumn{2}{c}{$\mathbf{2 2 - 2 3}$} & \multicolumn{2}{c}{ 24 ve üzeri } \\
\cline { 2 - 9 } & $\mathbf{f}$ & $\mathbf{\%}$ & $\mathbf{f}$ & $\mathbf{\%}$ & $\mathbf{f}$ & $\mathbf{\%}$ & $\mathbf{f}$ & $\mathbf{\%}$ \\
\hline $\begin{array}{l}\text { Uyum ve birliktelik unsuru } \\
\text { olarak eşlik dersi }\end{array}$ & 5 & 26,3 & 4 & 12,1 & 14 & 41,2 & 2 & 11,1 \\
\hline $\begin{array}{l}\text { Kaygı kaynağı olarak eşlik } \\
\text { dersi }\end{array}$ & 1 & 5,3 & 5 & 15,2 & 1 & 2,9 & 2 & 11,1 \\
\hline $\begin{array}{l}\text { Heyecan ve mutluluk } \\
\text { kaynağı olarak eşlik dersi }\end{array}$ & 3 & 15,8 & 2 & 6,1 & 3 & 8,8 & 5 & 27,8 \\
\hline $\begin{array}{l}\text { Zorunlu bir ihtiyaç olarak } \\
\text { eşlik dersi }\end{array}$ & 2 & 10,5 & 2 & 6,1 & 1 & 2,9 & 3 & 16,7 \\
\hline
\end{tabular}




\begin{tabular}{lcccccccc}
$\begin{array}{l}\text { Tamamlayicı bir unsur } \\
\text { olarak eşlik dersi }\end{array}$ & 3 & 15,8 & 10 & 30,3 & 4 & 11,8 & 2 & 11,1 \\
\hline $\begin{array}{l}\text { Destekleyici bir unsur } \\
\text { olarak eşlik dersi }\end{array}$ & 2 & 10,5 & 7 & 21,2 & 8 & 23,5 & 3 & 16,7 \\
\hline $\begin{array}{l}\text { Yol gösterici, öğretici bir } \\
\text { unsur olarak eşlik dersi }\end{array}$ & 3 & 15,8 & 3 & 9,1 & 3 & 8,8 & 1 & 5,7 \\
\hline Toplam & 19 & 100 & 33 & 100 & 34 & 100 & 18 & 100 \\
\hline
\end{tabular}

Tablo 5’te öğrencilerin eşlik dersine ilişkin metaforik yaklaşımlarına yönelik oluşturulan kategorilerin yaş değişkeni bağlamında dağılımları verilmiştir. Bu dağılımlara göre, 18-19 ve 22-23 yaş aralığındaki öğrenciler eşlik dersini en çok uyum ve birliktelik kaynağı olarak; 20-21 yaş aralığındaki öğrenciler tamamlayıcı bir unsur olarak; 24 ve üzeri yaş aralığındaki öğrenciler ise heyecan ve mutluluk kaynağı olarak görmektedir.

Tablo 6. “Eşlik Dersi”ne İlişkin Kategorilerin Branş Değişkeni Bağlamında Dağılımı

\begin{tabular}{|c|c|c|c|c|c|c|c|c|}
\hline \multirow{2}{*}{ Kategori } & \multicolumn{2}{|c|}{ Opera } & \multicolumn{2}{|c|}{ Yaylı Çalgılar } & \multicolumn{2}{|c|}{ Üflemeli Çalgılar } & \multicolumn{2}{|c|}{ Piyano ve Gitar } \\
\hline & f & $\%$ & f & $\%$ & f & $\%$ & f & $\%$ \\
\hline $\begin{array}{l}\text { Uyum ve birliktelik unsuru } \\
\text { olarak eşlik dersi }\end{array}$ & 10 & 14,3 & 7 & 46,7 & 5 & 38,5 & 3 & 50 \\
\hline $\begin{array}{l}\text { Kaygı kaynağı olarak eşlik } \\
\text { dersi }\end{array}$ & 8 & 11,4 & 0 & 0 & 1 & 7,7 & 0 & 0 \\
\hline $\begin{array}{l}\text { Heyecan ve mutluluk } \\
\text { kaynağı olarak eşlik dersi }\end{array}$ & 10 & 14,3 & 1 & 6,7 & 1 & 7,7 & 1 & 16,7 \\
\hline $\begin{array}{l}\text { Zorunlu bir ihtiyaç olarak } \\
\text { eşlik dersi }\end{array}$ & 7 & 10 & 0 & 0 & 1 & 7,7 & 0 & 0 \\
\hline $\begin{array}{l}\text { Tamamlayıcı bir unsur } \\
\text { olarak eşlik dersi }\end{array}$ & 12 & 17,1 & 4 & 26,7 & 2 & 15,4 & 1 & 16,7 \\
\hline $\begin{array}{l}\text { Destekleyici bir unsur } \\
\text { olarak eşlik dersi }\end{array}$ & 17 & 24,3 & 3 & 20 & 0 & 0 & 0 & 0 \\
\hline $\begin{array}{l}\text { Yol gösterici, öğretici bir } \\
\text { unsur olarak eşlik dersi }\end{array}$ & 6 & 8,6 & 0 & 0 & 3 & 23,1 & 1 & 16,7 \\
\hline Toplam & 70 & 100 & 15 & 100 & 13 & 100 & 6 & 100 \\
\hline
\end{tabular}

Tablo 6'da öğrencilerin eşlik dersine ilişkin metaforik yaklaşımlarına yönelik oluşturulan kategorilerin branş değişkeni bağlamında dağılımları verilmiştir. Bu dağılıma göre, opera öğrencileri eşlik dersini en çok ana branşı destekleyici bir unsur olarak görürken, yaylı çalgılar, üflemeli çalgılar, piyano ve gitar öğrencileri ise en çok uyum ve birliktelik unsuru olarak görmektedir. Eşlik dersini uyum ve birliktelik olarak nitelendiren öğrencilerin her performans alanında ağırlıklı olduğu görülmektedir. Eşlik dersini kaygı kaynağı olarak nitelendiren öğrencilerin performans alanlarının, ağırlıklı olarak şan ve nefesli çalgılar olduğu görülmektedir. 




Şekil 1. Konservatuvar Öğrencilerinin Eşlik Dersine Yönelik Metaforik Yaklaşımlarının Cinsiyet Değisşkeni Bağlamında Yüzdesel Dă̆ılımı

Konservatuvar öğrencilerinin eşlik dersine ilişkin metaforik yaklaşımları cinsiyet değişkeni bağlamında incelendiğinde, en belirgin farklılığın "Heyecan ve mutluluk kaynağı olarak eşlik dersi” kategorisinde ortaya çıktığı görülmektedir. Buna göre erkek öğrenciler, kız öğrencilere göre belirgin şekilde eşlik dersinden daha fazla heyecan ve mutluluk duymaktadır. Erkek öğrencilerden hiçbirinin eşlik dersini zorunlu bir ihtiyaç olarak görmemesi de bu tespiti destekler niteliktedir. Kız öğrenciler ise erkek öğrencilere göre daha yoğun olarak eşlik dersini, branş dersinin tamamlayıcı bir unsuru olarak görmektedir. 




Şekil 2. Konservatuvar Öğrencilerinin Eşlik Dersine Yönelik Metaforik Yaklaşımlarının Sınıf Değişkeni Bağlamında Yüzdesel Dağılımı

Konservatuvar öğrencilerinin eşlik dersine ilişkin metaforik yaklaşımları sınıf değişskeni bağlamında incelendiğinde, hazırlık sınıfı öğrencilerinde "uyum ve birliktelik", "heyecan ve mutluluk kaynağı”, “destekleyici unsur” kategorilerinin, lisans 1. sınıf öğrencilerinde ise belirgin bir şekilde “destekleyici unsur” kategorisinin öne çıktığı görülmektedir. Bu durum, lisans 1. sınıfta öğrencilerin eşlik dersine yönelik yaklaşımlarında ana çalgılarına ilişkin kazanımları ön planda tuttuklarını, eşlik dersini ise ana çalgılarını destekleyici bir unsur olarak gördüklerini göstermektedir. Lisans 2. sınıf ortalamaları değerlendirildiğinde, eşlik dersine ilişkin kaygı oranında diğer sınıflara oranla artış olduğu söylenebilir. Lisans 3. ve lisans 4. sınıflarda eşlik dersine yönelik algıların en çok uyum ve birliktelik kategorisinde yoğunlaştığı görülmektedir. 


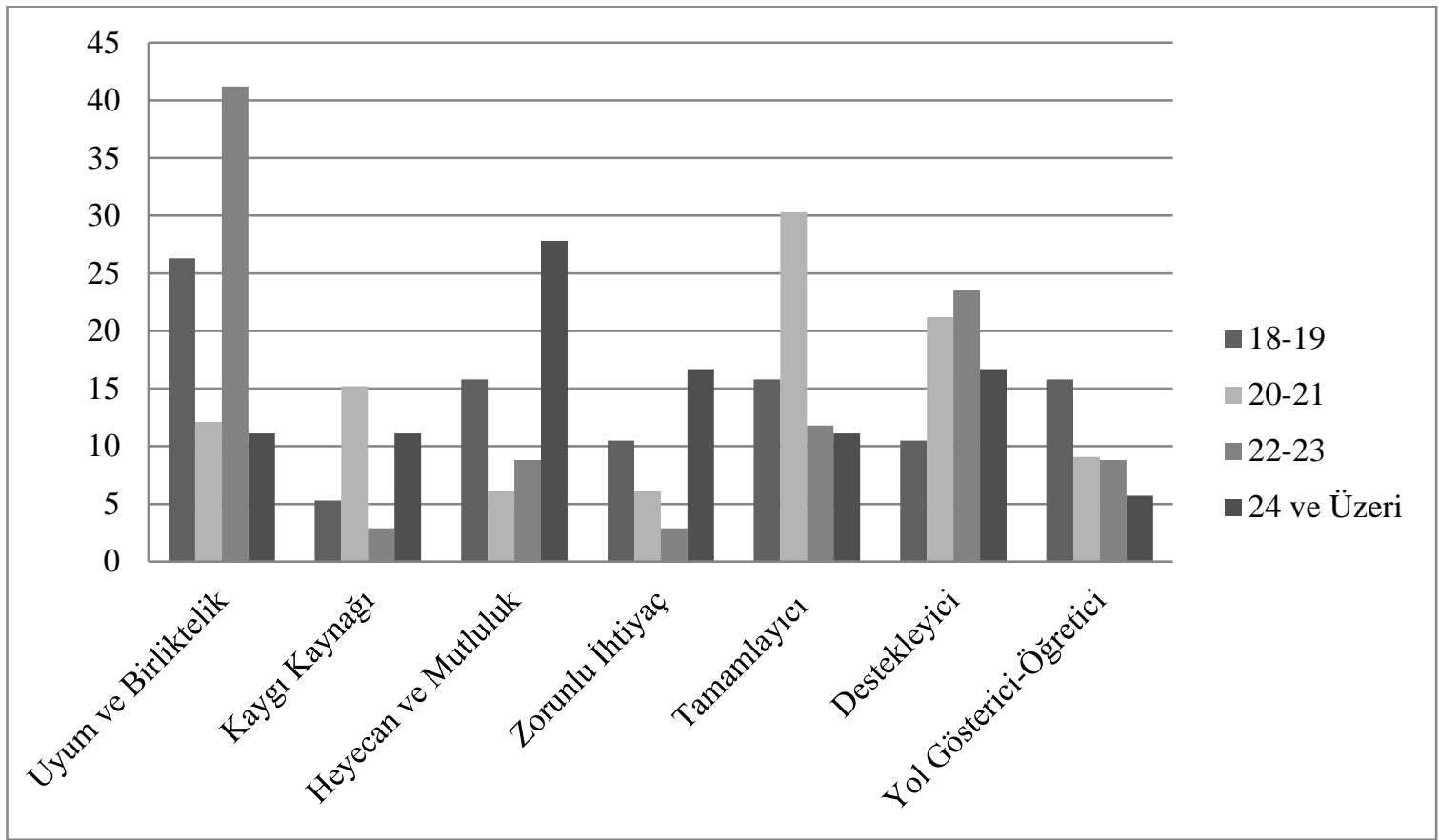

Şekil 3. Konservatuvar Öğrencilerinin Eşlik Dersine Yönelik Metaforik Yaklaşımlarının Yaş Değişkeni Bağlamında Yüzdesel Dağılımı

Konservatuvar öğrencilerinin eşlik dersine ilişkin metaforik yaklaşımları yaş değişkeni bağlamında incelendiğinde, 18-19 yaş aralığındaki öğrenciler eşlik dersini, diğer gruplara göre daha yol gösterici ve öğretici bulmaktadır. 20-21 yaş grubundaki öğrenciler eşlik dersini diğer gruplara göre daha fazla yoğunlukta tamamlayıcı bir ders olarak görürken, aynı zamanda eşlik dersini diğer gruplara göre daha çok kaygı kaynağı olarak görmektedirler. 22-23 yaş aralığındaki öğrencilerin eşlik dersini diğer gruplara göre daha çok uyum ve birliktelik kaynağı ve destekleyici bir unsur olarak gördükleri anlaşılmaktadır. 24 ve üzeri yaş grubunda en dikkat çekici husus, bu yaş grubunun diğer gruplara oranla eşlik dersini daha çok heyecan ve mutluluk kaynağı olarak görmeleridir. 


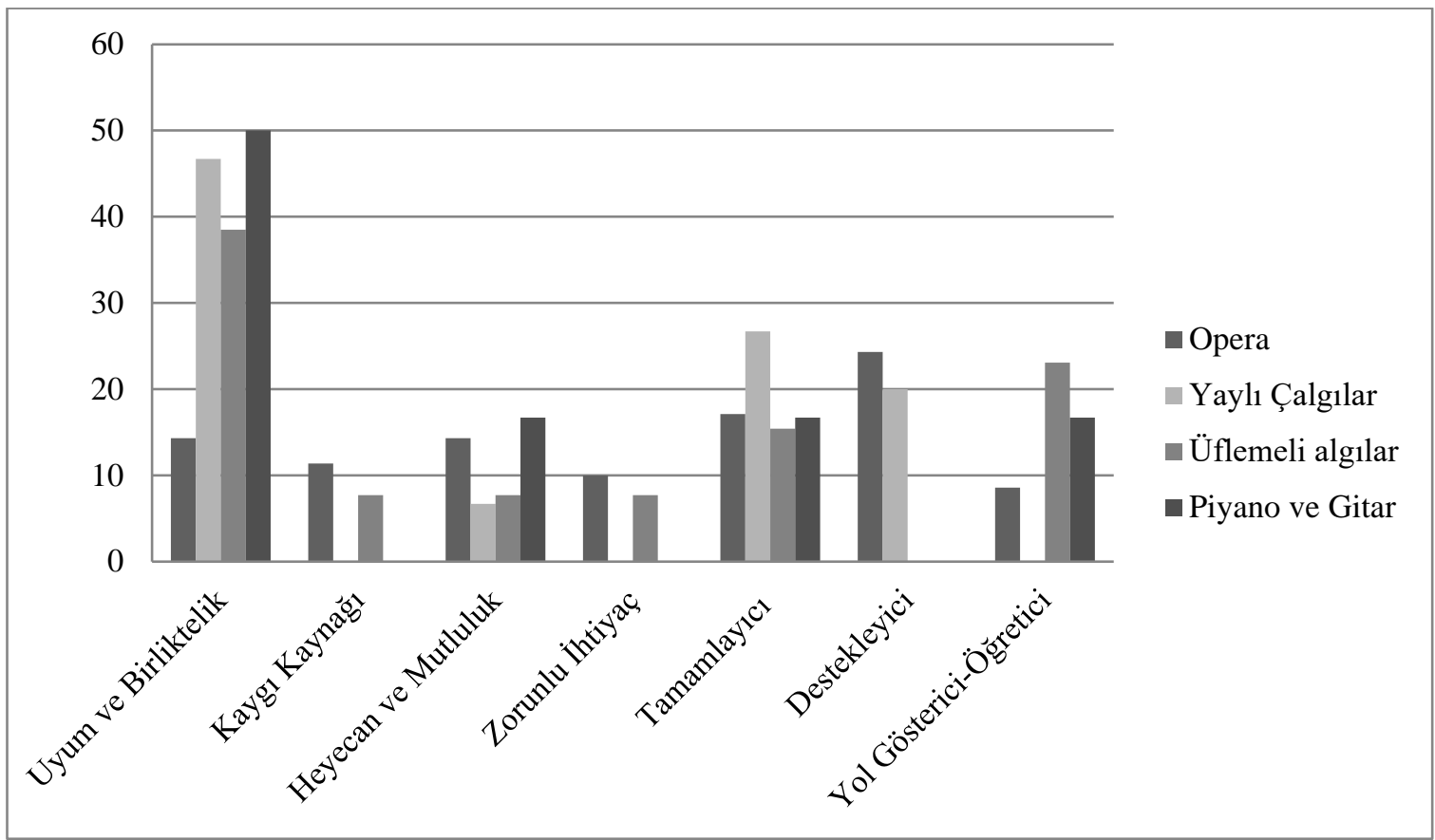

Şekil 4. Konservatuvar Öğrencilerinin Eşlik Dersine Yönelik Metaforik Yaklaşımlarının Branş Değişkeni Bağlamında Yüzdesel Dağılımı

Konservatuvar öğrencilerinin eşlik dersine ilişkin metaforik yaklaşımları branş değişkeni bağlamında incelendiğinde, kategorilerin genel dağılımına uygun olarak branş bağlamında da uyum ve birliktelik kategorisinin yüzdelerinin yaylı çalgılar, üflemeli çalgılar, piyano ve gitar alanlarında yüksek olduğu görülmektedir. Opera branşındaki öğrencilerin ise eşlik dersini en çok destekleyici bir unsur olarak gördükleri anlaşılmaktadır. Opera branşındaki öğrencilerinin eşlik dersini diğer branşlara oranla daha fazla oranda kaygı kaynağı olarak görmeleri dikkat çekicidir. Opera öğrencileri eşlik dersini diğer branşlara göre daha yüksek oranda destekleyici bir unsur olarak görürken, yaylı çalgılar öğrencileri diğer branşlara göre daha yüksek oranda tamamlayıcı olarak nitelemektedir.

\section{Sonuç, Tartışma ve Öneriler}

Araştırma sonucunda konservatuvar öğrencilerinin eşlik dersine ilişsin metaforik yaklaşımlarının kategorilere göre sırasıyla şu şekilde olduğu görülmüştür: Uyum ve birliktelik (\%24),destekleyici (\%19,2), tamamlayıcı(\%18,3), heyecan ve mutluluk kaynağı $(\% 12,5)$, yol gösterici-öğretici(\%9,6), kaygı kaynağı $(\% 8,7)$, zorunlu bir ihtiyaç $(\% 7,7)$.

Uyum ve Birliktelik Unsuru Olarak Eşlik Dersi: Araştırma sonucunda konservatuvar öğrencilerinin eşlik dersi ile ilgili ürettikleri metaforların en çok "uyum ve birliktelik" 
kategorisinde yer aldığı görülmektedir (\%24). Müziksel anlamda uyum, müziği meydana getiren öznelerin, bireysel müzikal ifadelerinin, müziğin bütünsel yapısı içinde karşılıklı olarak müzikal beklentilerini gerçekleştirmesi durumu olarak tanımlanabilir. Bir başka deyişle eşlik dersinde uyumun, müzikal ifade boyutunda öğrenci ve öğretmenin müzikal istek ve beklentilerinin ortak bir anlayış, ahenk ve bütünlükle icra edebilme unsurlarını barındırdığı söylenebilir. Eşlik dersi, öğrenci ve öğretmenin iki tarafın birlikteliğine (ansamblına) dayanan işbirlikli bir ders olarak tanımlanabilir. İcracılar arasında ses dengesi (balansı), ortak zamanlama, nüansların ortak hissedilerek yansıtılması gibi yoruma ait diğer unsurlar, sürekli bir uyum ve birliktelik içerisinde icrayı gerçekleştiren bireyler tarafından kontrol altında tutulmalıdır. $\mathrm{Bu}$ eylemlerin tümü uyum ve birliktelik olarak tanımlanabilir ve icrada birlikteliğin (ansamblın) başarılı olmasına katkı sağlar. Eşlik dersinde eğitimci ve öğrenci eser üzerinde zamanlama, stil, dönem, nüans gibi özelliklere göre ortak bir yoruma ve icraya ulaşmaya çalışır. Bu süreçte işbirlikli bir odakla eserin, müzikal sunumuna dair uyum ve birliktelik içerisinde ortak bir yoruma ulaşılmaya çalışılır. Araştırmanın sonuçlarına göre, uyum ve birliktelik unsuru, ağırlıklı olarak her performans alanında eşlik dersine ilişkin en çok tercih edilen yaklaşım (\%24) olarak belirtilmektedir. Uyum ve birliktelik unsurunun ortak bir eylemi çağrıştırdığı düşünülürse, bu yaklaşımın eşlik dersiyle oldukça örtüştüğü varsayılabilir.

Destekleyici Bir Unsur Olarak Eşlik Dersi: Araştırma kapsamında öğrencilerin \%19,2'si eşlik dersini destekleyici bir unsur olarak ifade etmişlerdir. Eşlikle çalma; öğrencinin birlikte söyleme, müzikal uyum, stil-form kavrama becerilerini geliştirirken entonasyon problemlerinin de en aza indirgenmesine yardımcı olur (Çanakçı \& Kaptanoğlu 2015, s.199). Bu bağlamda eşlikle çalmanın, müzikal uyumun, stil-form kavrama becerilerinin geliştirilmesi ve entonasyon problemlerinin giderilmesinde destekleyici bir rol oynadığı söylenebilir. Eşlik dersini destekleyici bir unsur olarak gören öğrencilerin, çalgıları ile ilgili müziksel gelişimlerinde eşlik dersinin katkılarının farkında oldukları söylenebilir.

Tamamlayıcı Bir Unsur Olarak Eşlik Dersi: Araştırma sonucunda öğrencilerin \%18,3'ünün eşlik dersini tamamlayıcı bir unsur olarak gördükleri anlaşılmıştır. Yüksel'e göre (2010) müziğin sahip olduğu yapıya ve müzisyenlerin eserdeki pozisyonuna göre, partiler eşit ya da farklı önemlere sahip olabilir. Partilerin eşit öneme sahip olması durumunda müzisyenler birbirleri ile karşılıklı bir alıveriş içerisinde olurlar. Eşit önemde olmayan partilerin seslendirilmesinde ise çoğunlukla önemi az olan parti, önemi fazla olan partiye daha fazla uyum gösterme eğilimindedir (Yüksel, 2010, s.2-3). Eşlik dersi bağlamında çalışılan eserler açısından 
bir değerlendirme yapıldığında, eşlikçi ve öğrencinin partileri tek başına bir bütün oluşturmazken eşlik ve solo partisi birbirini tamamlayarak bir bütün haline gelmektedir. Öğrenci solo olarak çalıştığı partisini ancak eşlikle birlikte seslendirdiği zaman eserin bütününün ortaya çıkması mümkün olabilir. Eşlik dersinin amaçlarından biri de, öğrencinin eşliğin tamamlayıcı rolüne ilişkin belli bir müziksel bilinç düzeyine ulaşmasıdır. Bu bakımdan öğrencilerin eşlik dersini tamamlayıcı bir unsur olarak görmeleri, eşlik dersinin ontolojisini algılamaları bakımından önem taşımaktadır.

Heyecan ve Mutluluk Kaynağı Olarak Eşlik Dersi: Öğrencilerin \%12,5’i eşlik dersini heyecan ve mutluluk kaynağı olarak algılamaktadır. Öğrencilerin eşlik dersine yönelik hislerini ortaya koyan bu durum, aynı zamanda eşlik dersine yönelik duyuşsal kazanımları da ortaya koymaktadır. Gable ve Wolf'un (1993, s.4) belirttiği gibi, insan duyguları ya da hisler, duyuşsal alanın içine girmektedir. Sönmez de (2003, s.81) eğitim uygulamalarında duyuşsal boyutun bulunması gerektiğini ifade etmektedir. $\mathrm{Bu}$ bağlamda, araştırma sonucunda öğrencilerin eşlik dersine ilişkin kavrayışlarında duyuşsal bir boyutun ortaya çıkması olumlu unsur olarak değerlendirilebilir.

Yol Gösterici ve Öğretici Bir Unsur Olarak Eşlik Dersi: Araştırmaya katılan öğrencilerin \%9,6's1 eşlik dersini yol gösterici ve öğretici bir unsur olarak gördüklerini ifade ederken, öğretim sürecinin temel niteliklerine vurgu yapmışlardır. Nitekim eşlik dersinin temel amacı da, öğrencide müziksel açıdan istenilen davranışların oluşabilmesi için belirli bir metodolojik yaklaşımla öğrenmenin gerçekleşmesini sağlamaktır. Bu bakımından, bu kategoride yer alan öğrencilerin eşlik dersini müzik eğitimi sürecinin bir parçası olarak değerlendirdikleri söylenebilir.

Kaygı Kaynağı Olarak Eşlik Dersi: Araştırma sonuçlarına göre, öğrencilerin eşlik dersine ilişkin ürettikleri metaforlar bağlamında olumsuz olarak tanımlanabilecek tek kategori "kaygı kaynağı olarak eşlik dersi” kategorisidir (\%8,7). Bu kategoriye ilişkin üretilen metafor ve açıklamalar incelendiğinde, bu kategoride yer alan öğrencilerin eşlikle birlikte çalmanın zorluklarına yönelik kaygılarını ifade ettikleri anlaşılmaktadır. Eşlik dersinin en temel unsuru olan uyum ve birliktelik aynı zamanda pek çok zorluğu da beraberinde getirmektedir. Eşlik dersinin en temel amacı, solo partiyi seslendiren öğrenci ile eşlik partisini çalan öğretmenin aynı müzikal yaklaşımı göstermesi ve bu müzikal biçemi mükemmel bir uyum içinde gerçekleştirebilmeleridir. $\mathrm{Bu}$ bakımdan, öğrencinin çalgısını seslendirmedeki başarısı tek başına yeterli olmamaktadır. Eşlik dersine ilişkin öğrenci ve öğretmenin ortak bir müzikal 
ifadede buluşma zorunluluğunun öğrenciler tarafından bir kaygı kaynağı unsuru olduğu anlaşılmaktadır.

Zorunlu Bir İhtiyaç Olarak Eşlik Dersi: Çalışma grubunda yer alan öğrencilerin \%7,7'si eşlik dersini zorunlu bir ihtiyaç olarak görmektedir. Eğitim süreçlerinde zorunluluk ifadesi isteksiz dahi olsa yapma yükümlülüğü anlamıyla ele alındığında olumsuz bir ifade olarak algılanabilir. Kratzer de (1981, s.111) zorunluluğu yükümlülük kipi ile ilişkilendirir. Ancak eşlik dersi bağlamında oluşturulan metaforlar ve açıklamaları açısından bir değerlendirme yapıldığında, öğrencilerin belirttiği “zorunlu ihtiyacın” vazgeçilmezlik bağlamıyla ilişkili olduğu değerlendirilebilir. Öğrenciler eşlik dersini çalgı eğitiminin vazgeçilmez bir parçası olarak görmektedirler. Bu bakımdan bu kategoride yer alan öğrencilerin, eşlik dersi olmaz ise branş eğitiminin de yapılamayacağı anlayışında oldukları söylenebilir.

Cinsiyet değişkenine ilişkin veriler, erkek öğrencilerin eşlik dersine yönelik yaklaşımlarının daha duyuşsal boyutta olduğunu, kız öğrencilerin yaklaşımının ise branş dersi odaklı olduğunu göstermektedir. Araştırmanın sonuçlarına göre, ağırlıklı olarak erkek öğrencilerin eşlik dersine yaklaşım ve nitelemelerinin duyuşsal alana ait olumlu bir yaklaşım ve niteleme olduğu görülebilir. Diğer yandan, bulgulara göre az bir farkla da olsa, eşlik dersini kız öğrencilerin daha çok kaygı kaynağı olarak nitelendirdikleri görülmektedir. Alanyazında birçok çalışmada müzik performans kaygısının erkeklere göre, kızlarda daha baskın olduğu belirtilmektedir (Osborne \& Kenny, 2008; Çırakoğlu ve Şentürk, 2013). Bu bağlamda, kız öğrencilerin eşlik derslerine ilişkin yaklaşımlarının duyuşsal boyutta olumlu bir yaklaşımdan daha çok, birlikte müzik yapabilmek için bir gereklilik gibi nitelendirildiği varsayılabilir.

Sınıf değişkeni bağlamında genel bir değerlendirme yapıldığında, öğrencilerin eşlik dersine yaklaşımlarının akademik gelişimleri ile doğru orantılı olduğu söylenebilir. Hazırlık sınıfı öğrencilerinin dağılımlarında belirgin bir kategori öne çıkmazken, lisans 1. sınıf öğrencilerinin çalgılarına yöneldikleri ve eşlik dersini ana branşlarına yönelik kazanımları destekleyici nitelikte gördüğü anlaşılmaktadır. Öğrencilerin daha büyük ölçekli eserleri çalışmaya başladıkları lisans 2. sınıfta eşlik dersine ilişkin kaygı düzeyinin arttığı, lisans 3. ve 4. sınıflarda ise eşlik dersini müzikal olgunluğun bir göstergesi olarak kabul edilebilecek olan uyum ve birliktelik olarak gördükleri anlaşılmaktadır. Eşlik dersi aşamalı olarak müzikal uyum ve birlikte müzik yapabilmenin ilke ve prensiplerinin öğrenildiği bir ders olarak tanımlanabilir. İlk sınıflarda ise müzikal uyum ve birlikteliğin deneyim azlığına bağlı olarak, her zaman 
istenilen seviyede gerçekleştirilemediği sıklıkla gözlemlenebilir. Eşlik dersinin aşamalı olarak devam etmesi ve gelişmesiyle beraber 3. ve 4. sınıflarda öğrencinin müzikal birlikteliğe ilişkin deneyimi ve becerilerinin artmasıyla, eşlik dersini "heyecan ve mutluluk kaynağg” olarak nitelendirmeleri, dersin eğitim hedefleriyle örtüşen bir sonuç olduğu varsayılabilir.

Yaş değişkenine ilişkin verilere göre, eşlik dersini yeni almaya başlayan 18-19 yaş grubunun eşlik dersini diğer yaş gruplarına kıyasla daha yol gösterici ve öğretici bulmaları, eğitim sürecinin doğal bir sonucudur. 20-21 yaş grubunun eşlik dersini diğer gruplara göre daha az heyecan ve mutluluk kaynağı olarak görmesi, kaygı oranın artması ile açıklanabilir. 22-23 yaş grubundaki öğrencilerin eşlik dersine ilişkin yaklaşımları değerlendirildiğinde, diğer gruplara göre daha fazla yoğunlukta ana çalgı ve eşlik dersinin farklı boyutlarını bir bütün içinde algıladıkları söylenebilir. Büyük yaş gruplarında eşlik dersine ilişkin akademik kaygılardan daha çok duyusal bir tatmin beklentisi olduğu değerlendirilebilir. Yukarıda belirtilen sonuçlara göre, büyük yaş gruplarında eşlik dersinin daha çok uyum ve birliktelik olarak nitelendirilmesi, eşlik dersine ilişkin bilişsel yaklaşımın büyük yaş gruplarında daha bilinçli olduğu varsayımına dayandırılabilir.

Branş değişkenine ilişkin verilere göre, yaylı çalgılar öğrencilerinin eşlik dersi olmadan branş derslerinin eksik kalacağını düşündükleri, opera öğrencilerinin ise eşlik dersinin branş dersini sadece katkı sunduğu yönünde bir düşünceye sahip oldukları anlaşılmaktadır. Üflemeli çalg1 öğrencileri, diğer branşlara göre eşlik dersini daha yüksek oranda yol gösterici ve öğretici bulmaktadır. Eşlik dersini kaygı (\%8,7’si) kaynağı olarak nitelendiren öğrencilerin performans alanlarının, ağırlıklı olarak şan ve nefesli sazlar olduğu görülmektedir. Eşlik dersinde müzikal uyum ve zamanlama en belirleyici göstergeler olarak tanımlanabilir. Zamanlama açısından düşünüldüğünde şancıların nefes ve solunum üzerinden performans yapmalarına bağlı olarak hem söz, hem de nefesler açısından notada yazılan ritim ve tempoyu daha serbest hissedebilecekleri ve yorum yapabilecekleri söylenebilir. Aynı şekilde nefesli saz çalan öğrencilerin de nefes ve solunum üzerinden performans yapmalarına bağlı olarak nefesi kullanma kapasitesi ve yeterliliği açısından notada yazılan ritim ve tempoyu daha serbest hissedebilecekleri ve yorum yapabilecekleri söylenebilir. Bu bağlamda eşlikçiyle uyumlu bir müzikal birliktelik gerçekleştirmelerinin olumsuz anlamda etkilenebileceği söylenebilir. Performans alanı şan ve nefesli sazlar olan öğrencilerin diğer enstrümanlara kıyasla eşlik dersini daha kaygı verici olarak nitelendirmeleri, şan ve nefesli sazların performans koşulları bağlamında anlaşılabilir bir olgu olarak kabul edilebilir. Tablo 7’de öğrencilerin eşlik dersine 
ilişkin metaforik yaklaşımlarına yönelik oluşturulan kategorilerin branş değişkeni bağlamında dağılımları verilmiştir. Bu dağılıma göre, opera öğrencileri eşlik dersini en çok ana branşı destekleyici bir unsur olarak görürken, yaylı çalgılar, üflemeli çalgılar, piyano ve gitar öğrencileri ise en çok uyum ve birliktelik unsuru olarak görmektedir. Opera öğrencilerinin eşlik dersini ana branşı tamamlayıcı ve olumlu sayılabilecek bir unsuru olarak nitelendirmeleri, çoğunlukla şan performansının doğasına özgü birliktelik (ansamblı) gerektiren bir performans anlayışına sahip olması sebebiyle beklenen bir sonuç olarak görülebilir. Araştırmanın tüm sonuçları incelendiğinde, enstrüman ve performans alanı kategorilerinin eşlik dersine ilişkin ortak yaklaşımlarının yanı sıra, farklı yaklaşımlarının da olduğu görülmektedir. Bu sonuca göre, her enstrüman kategorisi ve performans alanının eşlik dersinden farklı beklenti ve ihtiyaçları olduğu kanısına varılabilir.

Araştırma sonuçları ile ilgili genel bir değerlendirme yapıldığında;

- Öğrencilerin her performans alanında ağırlıklı olarak, eşlik dersini uyum ve birliktelik olarak nitelendirdikleri, bu sonucun da eşlik dersinin temel hedef ve amaçlarıyla örtüştügü söylenebilir. Bununla birlikte, opera/şan branşındaki öğrencilerin eşlik dersini en çok destekleyici bir unsur olarak gördükleri anlaşılmaktadır. Ancak, eşlik dersinin temel amaç ve hedeflerinin müzikal birliktelik ve müzikal uyum olduğu düşünüldüğünde, opera bölümü öğrencilerinin eşlik dersine ilişkin ağırlıklı yaklaşımlarının destekleyici yönünde olması, bu dersin temel amaç ve hedeflerinin bilinçli bir şekilde kavranamadığı şeklinde yorumlanabilir. $\mathrm{Bu}$ bağlamda opera öğrencilerinin bu nitelendirmelerine dair bilişsel, duyuşsal, somatik ve psikolojik eğilimleri üzerine araştırılmalar yapılmasının önemli olduğu söylenebilir.

- Eşlik dersini kaygı kaynağı olarak nitelendiren öğrencilerin performans alanlarının, ağırlıklı olarak şan ve nefesli çalgılar olduğu görülmektedir. Bununla birlikte, eşlik dersini kaygı kaynağ1 olarak gören şan ve nefesli sazlar öğrencileri ile kız öğrencilere dair bilişsel, duyuşsal ve somatik unsurlar bağlamında araştırmalar yapılması önerilebilir.

- Konservatuvar öğrencilerinin eşlik dersine ilişkin metaforik yaklaşımları öğrencilerin akademik gelişimlerine göre sınıf düzeyinde farklılıklar göstermektedir. Bununla birlikte 3. ve 4. sınıflarda müzikal birliktelik/uyum deneyimlerinin artması ve müzikal anlayışlarının olgunlaşmasıyla beraber, uyum ve birliktelik unsurunu öne çıkartmaları, eşlik dersinin doğasına uygun bir tanımlama ve bu dersin amacıyla oldukça uyumlu bir sonuç olarak tanımlanabilir. Bu bağlamda ilk ve son sınıflarda, enstrüman kategorileri ve performans alanlarının eşlik dersinden ihtiyaç ve beklentilerine yönelik bir araştırma yapılması önerilebilir. 
YYÜ Eğitim Fakültesi Dergisi (YYU Journal of Education Faculty), 2020; 17(1)1415-1443,http://efdergi.yyu.edu.tr,

- Her enstrüman ve performans alanı kategorisinin ortak yaklaşımlarının yanı sıra, eşlik dersine ilişkin farklı yaklaşımların da olduğu görülmektedir. Bu sonuca göre, her enstrüman kategorisi ve performans alanının eşlik dersine ilişkin ihtiyaç ve beklentilerine dair araştırma yapılması önerilebilir.

- Eşlik dersinin, konservatuvar performans geleneğinde birliktelik (ansamblı) açısından önemli bir ders olduğu ilgili alanyazında da çeşitli kaynaklarda belirtilmekte ve bu araştırmanın sonuçları da alanyazınla örtüşmektedir. Araştırmanın sonuçlarına göre, enstrüman kategorileri ve performans alanına göre eşlik dersine yönelik beklentilerin ve eşlik dersine ilişkin kaygı kaynaklarının daha detaylı araştırılması önerilebilir.

\section{Makalenin Bilimdeki Konumu}

Müzik, Müzik Eğitimi, Konservatuvar Eğitimi, Piyano Eşliği Eğitimi, Korrepetisyon

\section{Makalenin Bilimdeki Özgünlüğü}

Literatürde piyano eşliği ile ilgili değişik bakış açılarına değinilen çalışmalara yer verilmektedir. Ancak eşlik dersine ilişkin farklı enstrümanları çalan öğrencilerin metaforik yaklaşımlarının ortaya çıkarıldığı bir çalışmaya yer verilmediği tespit edilmiştir. Bu bağlamda araştırma sonucunda eşlik dersinin kapsamına ve içeriğine yönelik önemli tespitler ve ihtiyaçları ortaya koyması bakımından literatüre önemli katkılar sağladığı düşünülmektedir.

\section{Kaynaklar}

Akdeniz, A. \& Çarkçı, E. (2017). Konservatuvar Öğrencilerinin “Sanat Eğitimi” Kavramına İlişkin Metaforik Algıları. Mustafa Kemal Üniversitesi Sosyal Bilimler Enstitüsü Dergisi,14(40), 59-85.

Artaç, A. (2012). Operaların Piyano Eşliklerinin Yorumlanması. Uludă̆ Üniversitesi FenEdebiyat Fakültesi Sosyal Bilimler Dergisi, 23, 227-242.

Çırakoğlu, O. C., Şentürk G. C. (2013). Development of a Performance Anxiety Scale for Music Students. Science \& Medicine, 199-206.

Demir, G. Y. (2005). Çevirenin önsözü. G. Lakoff \& M. Johnson (Yazarlar) Metaforlar: Hayat, Anlam ve Dil. İstanbul: Paradigma.

Demirci, K. (2016). Metafor: Bir Anlatım ve Üretim Mekanizması. Dil Bilimleri Kültür ve Edebiyat, (Editörler: M. Sarıca, B. Sarıca), Ankara: Padam Yayınları, 330-343. 
YYÜ Eğitim Fakültesi Dergisi (YYU Journal of Education Faculty), 2020; 17(1)1415-1443,http://efdergi.yyu.edu.tr,

Erdamar, F. S .\& Akpunar, F. (2017). Branş Öğretmenlerinin Eğitim Araştırmalarına Yönelik Algısı: Metaforik Bir Çalışma. Dicle Üniversitesi Ziya Gökalp Eğitim Fakültesi Dergisi, 32, 837-852.

Gable, R. K. \& Wolf, M. B. (1993). Instrument Develpoment in the Affective Domain: Measuring Attitudes and Values in Corporate and School Setting, (2nd Edition), Kluwer Academic Publishers, Boston-Dordrecht-London.

Gültekin, M. (2013). İlköğretim Öğretmen Adaylarının Eğitim Programı Kavramına Yükledikleri Metaforlar. Ĕ̈itim ve Bilim Dergisi, 38(169), 126-141.

Kalyoncu, R. (2012). Görsel sanatlar öğretmeni adaylarının “öğretmenlik” kavramına ilişkin metaforları. Mustafa Kemal Üniversitesi Sosyal Bilimler Enstitüsü Dergisi, 9(20), 471484.

Kaptanoğlu, Ç. ve Çanakçı, P. (2015). Türkiye'de Vokal Müzikte Piyano Eşlik Alanında Yapılmış Yüksek Lisans, Doktora ve Sanatta Yeterlik Tezleri. Elektronik Sosyal Bilimler Dergisi, ISSN:1304-0278, 14(55), 198-206.

Kömürcü, H. (2019). Bilgisayar Destekli Piyano Eşlikleme Yönteminin Şan ve Korrepetisyon Eğitimi Alanındaki Etkililiği. (Yayımlanmamış Doktora Tezi). Gazi Üniversitesi Eğitim Bilimleri Enstitüsü, Ankara.

Kratzer, A. (1981). The National Category of Modality. Words, Worlds and Contexts- New Approaches in Word Semantis. Editor: Hans-Jurgen Eikmayer and Hannes Rieser, Berlin: Walter de Gruyter, 38-75.

Krippendorff, K. \& Bock, M. A. (2008). The Content Analysis Reader. London: Sage.

Lakoff, G. \& Johnson, M. (1980). Metaphors We Live By. Chicago and London: The University of Chicago Press.

Lakoff, G. ve Johnson, M. (2010). Metaforlar: Hayat, Anlam ve Dil. Çev: Gökhan Yavuz Demir. İstanbul: Paradigma Yayıncılık.

Miller, S. (2003). Analysis of phenomenological data generated with children as research participants. Nurse Researcher, 10(4), 68-82.

Osborne, M., Kenny, D. (2008). The role of sentisizing experience in music performance anxiety in adolescent musicians. Psychology of Music, vol 36(4), 447-463.

Örücü, D. (2014). Öğretmen Adaylarının Okul, Okul Yönetimi ve Türk Eğitim Sistemine Yönelik Metaforik Algıları. Kuram ve Uygulamada Eğitim Yönetimi Dergisi, 20(3), 327358. 
YYÜ Eğitim Fakültesi Dergisi (YYU Journal of Education Faculty), 2020; 17(1)1415-1443,http://efdergi.yyu.edu.tr,

Özaydın, N. (2019). Müzik Öğretmen Adaylarının “Ses” Kavramına İlişkin Metaforları. OPUS Uluslararası Toplum Araştırmaları Dergisi, 13(19), 332-358.

Pala, A., Zahal, O. ve Gürpınar, E. (2016). Müzik öğretmenlerinin ortaokul müzik derslerinde piyano-org çalgılarını kullanabilme durumları (Malatya ili örneği). 2. Uluslararası Müzik ve Dans Kongresi E-Bildiriler Kitabı, Ankara: Müzik Eğitimi Yayınları.

Patton, M. Q. (2002). Qualitative research and evaluation methods. (3. Bask1). Thousand Oaks: Sage.

Roussou, E. (2017). Exploring the piano accompanist in western duo music ensembles: towards a conceptual framework of professional piano accompaniment practice. (Unpublished Doctoral Thesis), University of Hull, England.

Roberge, M. A. (1993). From Orchestra to Piano: Major Composer as Authots of Piano Reductions of Other Composers. Notes, 49(3), 925-936.

Saban, A. (2008). Okula İlişkin Metaforlar. Kuram ve Uygulamada Eğitim Yönetimi, 55, 459496.

Shuell, J. T. (1990). Teaching and Learning as Problem Solving. Theory intoPractice, 29(2), 102-108.

Sönmez, V. (2003). Program Geliştirmede Öğretmen El Kitabı.(10. Baskı), Ankara: Anı Yayınc1lık.

Tavşanc1l, E. ve Aslan, E. (2001). İçerik Analizi ve Uygulama Örnekleri. İstanbul: Epilson Yayınları.

Tompkins, P. \& Lawley, J. (2002). Mind, Metaphor and Health. Positive Health Magazine, 78, 1-8.

Willig, C. (2008). Introducing Qualitative Research in Psychology. (2. Bask1). Berkshire: McGraw-Hill Professional Publishing.

Yıldırım, A. ve Şimşek, H. (2013). Sosyal Bilimlerde Nitel Araştırma Yöntemleri. (9. baskı). Ankara: Seçkin Yayınları.

Yüksel, K. (2010). Piyano Eşlikli Şan Performansında Eşlikçinin Algısal ve Psikomotor Becerileri, Deneyimi ve Piyanistik Düzeyinin Zamanlama Uyumuyla İlişkisi. (Yayımlanmamış Doktora Tezi). Gazi Üniversitesi Eğitim Bilimleri Enstitüsü, Ankara.

\section{Summary}

\section{Purpose and Significance}


The main purpose of this study is to determine the metaphorical approaches of conservatory students towards the "accompaniment course". The research is important in terms of revealing the perceptions and understandings of the conservatory students about accompaniment course through the metaphors.

\section{Methodology}

This study is a qualitative research and the phenomenology pattern is used. In phenomenology studies, it is aimed to reveal the meanings that an individual attribute to a phenomenon. The study group of the research consisted of 104 students selected by random sampling method among the conservatories. The form prepared by the researchers was used to obtain research data. In the form, besides the demographic information of the students, they were asked to complete the sentence “Accompaniment course is like. .because. .. The data obtained were analyzed by content analysis method. By content analysis, the metaphors developed by the conservatory students for the concept of "accompaniment course" were determined and the resulting metaphors were coded and categorized. Cross-tab analysis was used to determine whether there is a relationship between the categories of metaphors produced and the demographic variables of the students.

\section{Results}

As a result of the research, the metaphoric approaches of the conservatory students towards the accompaniment course were grouped into 7 categories. These categories are as follows respectively: “Accompaniment course as an element of harmony and togetherness (\%24)”, “Accompaniment course as a supportive element (\%19,2)”, “Accompaniment course as an complementary element (\%18,3)”, “Accompaniment course as a source of excitement and happiness (\%12,5)”, “Accompaniment course as guiding and instructive element $(\% 9,6)$ ”, "Accompaniment course as a source of anxiety (\%8,7)", “Accompaniment course as a compulsory necessity $(\% 7,7)$ ”. It is observed that the metaphors produced by the conservatory students related to the accompaniment course are mostly in the category of "harmony and togetherness". It is understood that female students perceive the "accompaniment course" most as a complementary element of the branch instrument (23\%), and the male students most as an harmony and togetherness element (30\%). The biggest difference between male and female students has emerged in perceive the accompaniment course as a source of excitement and happiness. In this category, the rate of male students is quite higher than female students. The preparatory class students see the accompaniment course as the element of harmony and 
togetherness, the source of excitement and happiness, and also supportive. Undergraduate students in the first year, see the accompaniment course most as a supporting course of the branch course. While undergraduate $2^{\text {nd }}$ year students consider the accompaniment course most as the complementary element, undergraduate $3^{\text {rd }}$ and $4^{\text {th }}$ graders see the accompaniment course most as the harmony and togetherness factor. Students between the ages of 18-19 and 22-23 are consider the accompaniment course most as the sources of harmony and togetherness. Students between the ages of 20-21 consider the accompaniment course most as a complementary element. Students over the age of 24 see it most as a source of excitement and happiness. Opera students see accompaniment course most as the supportive element of the main branch, while string instruments, wind instruments, piano and guitar students see most as harmony and togetherness.

\section{Discussion and Conclusion}

Musical togetherness can be defined as the common realization of musical expectations in the context of individual musical expressions of the musicians in the holistic structure of music. Accompaniment course can be defined as a collaborative course based on the unity of both students and teachers. Elements of expression such as sound balance, common timing, reflecting the nuances with common feelings (etc.) should be kept under control by individuals who perform in continuous harmony and unity. All of these actions can be defined as harmony and togetherness, and contributes to the success of the ensemble. In the accompaniment course, the teacher and the student study on timing, style, period, nuance (etc.) and tries to reach a common musical interpretation and expression based on such characteristics. Given that the element of harmony and togetherness evokes a common action; it can be assumed that this approach quite coincides with the accompaniment course. Accompaniment course play a supporting role in the development of musical harmony, style - form comprehension skills and the elimination of intonation problems. It can be said that the students, who consider the accompaniment course as a supportive factor, are aware of the contributions of the accompaniment course in their musical development related to their instruments. Playing of the accompanist or student do not form a whole musical composition by themselves. When the student plays with the accompaniment, it may be possible that the whole work is revealed. One of the aims of the accompaniment course for the student is to reach a certain level of musical consciousness regarding the complementary role of accompaniment. So, it is important for the students to perceive the ontology of the accompaniment course as a complementary element. 
Perceiving the accompaniment course as a source of excitement and happiness reveals the students' feelings for the accompaniment course and also reveals the affective gains for the accompaniment course. The occurrence of an affective dimension in the students' perception towards accompaniment course can be considered as a positive element as a result of the research. The main purpose of the accompaniment course is to provide the realization of learning with a specific methodological approach in order to create the desired musical behaviors in the student. In this respect, it can be said that the students in the category in which consider the accompaniment course as a guiding and instructive element evaluate the accompaniment course as part of the music education process. The only category that can be negatively defined in the context of the metaphors that students produce about the accompaniment course is the category "accompaniment course as a source of anxiety”. The main purpose of the accompaniment course is that the student who plays the solo part and the teacher who plays the accompaniment part show the same musical approach and style. It is understood that the requirement of the student and teacher to meet in a common musical expression is considered as an element of anxiety by the students. The students in the "compulsory necessity" category see the accompaniment course as an indispensable part of instrument education. In this respect, it can be said that the students in this category are in the understanding that if there is no accompaniment course, branch education cannot be done.

When the metaphorical approaches of the conservatory students to the accompaniment course are examined in the context of the gender, class, age and branch variables, the following conclusions have been reached.

Male students approach to the accompaniment course is more affective, while female students' approach is focused on the branch course. Male students' approach and description to the accompaniment course is a positive approach and qualification related to the affective field. There is more expectation of emotional satisfaction in older age groups rather than academic concerns about the accompaniment course. The high ratio of "harmony and togetherness" of the accompaniment course in older age groups can be based on the assumption that the cognitive approach to the accompaniment course is more conscious in older age groups. In the branch variable it is remarkable that the students in the opera branch regarded the accompaniment course as a source of anxiety more than other branches. The reason for this may be that the human voice, which is based on breath, is more difficult to be compatible with the piano compare to any other instruments. The performance areas of the students who describe the 
YYÜ Eğitim Fakültesi Dergisi (YYU Journal of Education Faculty), 2020; 17(1)1415-1443,http://efdergi.yyu.edu.tr,

accompaniment course as a source of anxiety are predominantly singing and woodwind instruments. Because their performances are breath-based, therefore may be they use rhythm and tempo flexibly.

In this context, it is understandable that they describe playing with accompaniment as more anxious than other instruments.

EK 1. Etik Kurul Kararı

Ankara Üniversitesi Etik Kurulu Sosyal Bilimler Alt Etik Kurulu’nun 30/03/2020 tarih ve 3/67 sayılı kararı gereği çalışma ilgili çalışmanın, etik açıdan uygun olduğuna oy birliği ile karar verilmiştir. 